\title{
オリゴマー製品等の分離分析
}

\author{
桑田信一郎*・藤 田 桂 一** \\ * 大蔵省関税中央分析所 (松戸市岩瀬 531) \\ ** 長崎税関輸入部（長崎市出島町 1 番 36 号）

\section{Separation Analysis of Chemical Products Containing Oligomers or Polymers}

Shin'ichiro Kuwata* and Keiichi Fujita**

* Central Customs Laboratory, Ministry of Finance (531, Iwase, Matsudo-shi, Chiba)

** Nagasaki Customs, Import Division (1-36, Dejimacho, Nagasaki-shi, Nagasaki)

\section{1 はじめに}

オリゴマーは液状で取り扱いが容易であったり, 環境 污染源の一つである溶媒が不必要であるなど, 数かずの 長所がみられるため, 接着剤や塗料等の製品に広く利用 されている。また, プレポリマーや変性剤等としての利 用も多い。

筆者らは, 輸入品の分析及び分析法の研究開発を行。 ているが, 対象とするほとんどの試料は, 成分内容が不 明である。その様な場合不揮発性の未知試料の分離分析 には, GPCが大変効果的である。一方, 揮 発性の化合 物に対しては, GC-MS を活用している。

本稿では, 主としてオリゴマーやポリマーの製品や原 料等について, GPC やGC-MS による分離分析の例を 中心に紹介したい。

また水溶性化合物の透析膜による分離分析の例も合わ せて紹介する。

\section{GPC による分離分析}

\section{$2 \cdot 1$ GPC における溶出量と分子量}

オリゴマーやポリマーの分別並びにキャラクタリゼー ションなどによく利用されている GPC は液体クロマト グラフィーの一種であるが，主として分子サイズによっ て分離が行われる点に大きな特長がある。そのため, 充 てん剂や溶媒の選択などの実験条件の検討にあまり留意 する必要がなく, 製品中のオリゴマーやポリマー並びに 低分子の添加剤の分離分析等, 未知試料の分析に非常に 有効である。GPC の理論や実験法については，すでに 多くの成書や報告1) 4) があるので，〈わしくはそれらを 参照願いたい。

筆者らは液体クロマトグラフ LC-08 型（日本分析工 業株式会社製) に, 分取用の GPCカラム（表 -1）を取 り付けて使用している。分取用カラムは, 分離能がわず かに低いが，試料を $150 \mathrm{mg}$ 程度も一度に注入でき, 各 分取成分について IR スペクトルや NMR スペクトル等 によって構造確認等ができるので, 未知試料に対して利 点が大きい。

表-1 に記したカラムを用いて測定した各種標淮物質 の溶出量 (elution volume, 以下 Ve と略記する) と分 子量を表 2 4 に示す。測定条件はいずれの場合も，ク

表-1 分取用 GPC カラム

\begin{tabular}{|c|c|c|c|c|}
\hline 力 & 厶 & JAIGEL $2 \mathrm{H}$ & JAIGEL 1H & JAIGEL 4 \\
\hline \multicolumn{2}{|c|}{ カラムサイズ $(\mathrm{mm})$} & $20 \phi \times 600 \times 2$ 本 & $20 \phi \times 600 \times 2$ 本 & $20 \phi \times 600 \times 4$ 本 \\
\hline \multicolumn{2}{|l|}{ 充てえゲル } & 橋 & ナ ポリ ス チ & \\
\hline \multicolumn{2}{|c|}{ 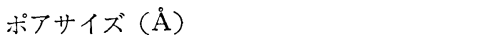 } & 100 & 25 & 25 \\
\hline \multicolumn{2}{|c|}{ 分離対象分子量 } & $100 \sim 5,000$ & $100 \sim 1,000$ & $100 \sim 1,000$ \\
\hline & $4,500 \mathrm{TP} / \mathrm{F}$ 以上 & $4,500 \mathrm{TP} / \mathrm{F}$ 以上 & $800 \mathrm{TP} / \mathrm{F}$ 以上 \\
\hline & 252 & 210 & 453 \\
\hline ポリスチレン & T. 10,000$)$ $\mathrm{Ve}(\mathrm{ml})$ & 108 & 101 & 173 \\
\hline
\end{tabular}

*: メーカ公称值 
表-2 JAIGEL 2H による標準化合物の溶出量 $(\mathrm{Ve})^{11)}$

\begin{tabular}{|c|c|c|c|}
\hline $\begin{array}{l}\text { グルー } \\
\text { プ }\end{array}$ & 標 準 化 合 物 & 分子量 & \begin{tabular}{|l} 
溶出量 \\
$(\mathrm{ml})$
\end{tabular} \\
\hline A & $\begin{array}{cr}\text { Polyethylene glycol } & 6000 \\
" \prime & 4000 \\
" & 2000 \\
" & 1000 \\
" & 600\end{array}$ & $\begin{array}{l}{[7500]} \\
{[3000]} \\
{[2000]} \\
{[1000]} \\
{[600]}\end{array}$ & $\begin{array}{l}109 \\
117 \\
127 \\
142 \\
155\end{array}$ \\
\hline B & $\begin{array}{cc}\text { Polypropylene glycol } & 4000 \text { (triol) } \\
\prime \prime & 3000(" \prime) \\
\text { Polypropylene glycol } & 2000(\text { diol) } \\
\prime \prime & 1000(" \prime)\end{array}$ & $\begin{array}{l}{[4000]} \\
{[3000]} \\
{[2000]} \\
{[1000]}\end{array}$ & $\begin{array}{l}120 \\
124 \\
128 \\
150\end{array}$ \\
\hline $\mathrm{C}$ & $\begin{array}{l}\text { Ethyl palmitate } \\
\text { Pentyl laurate } \\
\text { Pentyl octanoate } \\
\text { Methyl octanoalie }\end{array}$ & $\begin{array}{l}284 \\
270 \\
214 \\
158\end{array}$ & $\begin{array}{l}193 \\
196 \\
207 \\
218\end{array}$ \\
\hline $\mathrm{D}$ & $\begin{array}{l}\text { Tris ( } \alpha \text {-methylbenzyl) phenol } \\
\text { Bis }(\alpha \text {-methylbenzyl) phenol } \\
(\alpha-\text { Methylbenzyl) phenol }\end{array}$ & $\begin{array}{l}406 \\
302 \\
198\end{array}$ & $\begin{array}{l}196 \\
213 \\
239\end{array}$ \\
\hline $\mathrm{E}$ & $\begin{array}{l}\text { Castor oil } \\
\text { Tristearin } \\
\text { Distearin } \\
\text { Monostearin } \\
\text { Dimer acid }\end{array}$ & $\begin{array}{c}(932) \\
892 \\
625 \\
359 \\
(564)\end{array}$ & $\begin{array}{l}152 \\
154 \\
164 \\
181 \\
142\end{array}$ \\
\hline $\mathrm{F}$ & $\begin{array}{l}\text { Abietic acid } \\
\text { Dehydrogenated rosin } \\
\text { Polymerized rosin }\end{array}$ & $\begin{array}{c}302 \\
(300) \\
(604)\end{array}$ & $\begin{array}{l}195 \\
190 \\
175 \\
\end{array}$ \\
\hline G & $\begin{array}{l}\text { Aroclor } 5442 \text { (PCT) } \\
\text { Aroclor } 1254 \text { (PCB) }\end{array}$ & $\begin{array}{l}(506)^{\mathrm{a})} \\
(326)^{\mathrm{b})}\end{array}$ & $\begin{array}{l}226 \\
238\end{array}$ \\
\hline
\end{tabular}

[ ]: 平均分子量

( ) : 主成分の分子量

a)オクタクロロトリフェニルとして

b) ペンタクロロビフェニルとして

表-3 JAIGEL 1H による標準化合物の溶出量 $(\mathrm{Ve})^{13)}$

\begin{tabular}{|c|c|c|c|}
\hline グループ & 標 準 化 合 物 & $\begin{array}{l}\text { 分子量又 } \\
\text { 沙重合度 }\end{array}$ & $\begin{array}{c}\text { 溶出量 } \\
(\mathrm{ml})\end{array}$ \\
\hline \multirow{8}{*}{ A } & \multirow{8}{*}{ Polyethylene glycol } & $1,000^{*}$ & 109 \\
\hline & & $n=9$ & 122 \\
\hline & & $n=8$ & 125 \\
\hline & & $n=7$ & 130 \\
\hline & & $n=6$ & 136 \\
\hline & & $n=5$ & 143 \\
\hline & & $n=4$ & 151 \\
\hline & & $n=3$ & 160 \\
\hline \multirow{6}{*}{ B } & \multirow{6}{*}{ Polystyrene } & $n=8$ & 124 \\
\hline & & $n=7$ & 128 \\
\hline & & $n=6$ & 134 \\
\hline & & $n=5$ & 141 \\
\hline & & $n=4$ & 150 \\
\hline & & $n=3$ & 163 \\
\hline \multirow{4}{*}{ C } & $n$-Docosane & 311 & 154 \\
\hline & n-Hexadecane & 226 & 171 \\
\hline & n-Dodecane & 170 & 189 \\
\hline & $n$-Hexane & 86 & 225 \\
\hline
\end{tabular}

*: 平均分子量
表-4 JAIGEL 4 による標準化合物の溶出量 $(\mathrm{Ve})^{11)}$

\begin{tabular}{|c|c|c|c|}
\hline グループ| & 標 準 化 合 物 & 分子量 & $\begin{array}{l}\text { 溶出量 } \\
(\mathrm{ml})\end{array}$ \\
\hline \multirow{3}{*}{$\mathrm{A}$} & Methyl stearate & 298 & 291 \\
\hline & Pentyl octanoate & 214 & 319 \\
\hline & Methyl octnoate & 158 & 357 \\
\hline \multirow{4}{*}{ B } & Tris $(\alpha$-methyl benzyl $)$ phenol & 406 & 297 \\
\hline & Bis ( $-\alpha$-methyl benzyl) phenol & 302 & 342 \\
\hline & $(\alpha$-methyl benzyl) phenol & 198 & 408 \\
\hline & Phenol & 94 & 509 \\
\hline \multirow{3}{*}{$\mathrm{C}$} & Anthracene & 178 & 478 \\
\hline & Phenanthrene & 178 & 478 \\
\hline & Naphthalene & 128 & 482 \\
\hline \multirow{3}{*}{ D } & Benzene & 78 & 492 \\
\hline & Triphenyl & 230 & 397 \\
\hline & Diphenyl & 154 & 440 \\
\hline \multirow{3}{*}{$\mathrm{E}$} & Triphenylmethane & 244 & 381 \\
\hline & Diphenylmethane & 168 & 414 \\
\hline & Toluene & 92 & 467 \\
\hline
\end{tabular}

ロロホルムを溶媒とし，流速は $3.1 \mathrm{ml} / \mathrm{min}$ とした。ま た試料は濃度 3 5\%のもの妾 $3 \mathrm{ml}$ 注入した。検知器 は示差屈析計を用いた。

同族体など同系列の化合物においては, 分子量の対数 と Ve との間に直線関係が成立することはよく知られて いる。表-2 のデータについてそれらをプロットしたも のが 図-1 であり，同系列の化合物について，分子量の 対数と Ve との間に比較的よい直線関係が認められる。

表-3 及び 4 のデータについてプロットした場合も同様 な直線関係が得られた ${ }^{11), 13)}$ 。

同じ分子量の化合物でも, その化学構造が相違すると Ve の值は異なってくる。芳香族化合物は同分子量の脂 肪族化合物に比較すると Ve は大きい（図-1 の D 及び G)。このことは溶液中における芳香族化合物の回転半 径 (radius of gyration) が脂肪族化合物より小さいため と考えられる。同様に多分岐化合物む直鎖の化合物より Veが大きい。化学構造や分子サイズとVe の関係につい

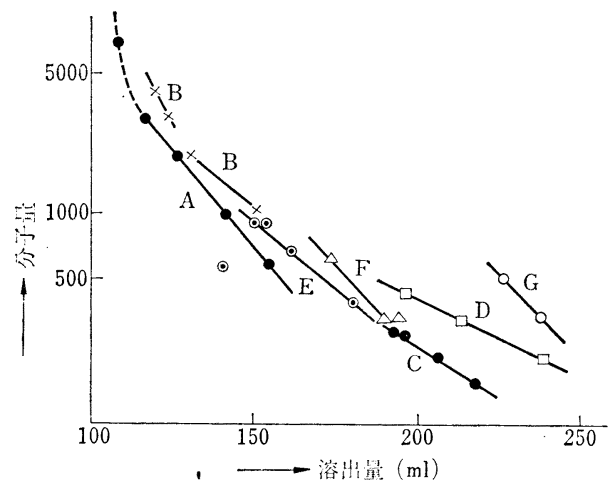

図-1 JAIGEL 2H による標準物質の溶出量と分子量 の関係 ${ }^{11}$ 


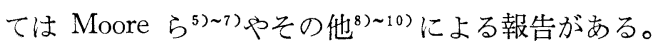

種々の標準物質について，その分子量と Ve の関係を 図-1 のようにグラフ化しておくと，実際の試料を分析 する場合に便利である。その化合物に直接該当する検量 線がない場合でも, 分子サイズ（または化学構造）が類 似していると思われる化合物の直線を検量線にしても， ごく大まかな分子量を推定できる場合が多い。

\section{$2 \cdot 2$ カルボン酸の $\mathrm{Ve}^{11) \sim 13)}$}

クロロホルムを溶媒とし, 注入試料濃度 $5 \%$ 程度で GPC を測定した場合，カルボン酸のVe は同じ分子量 のエステルやアルコールに比較して小さい(表-5)。ま たカルボン酸の Ve は注入試料の濃度によって変化する (図-2)。すなわち，エステルなどの検量線を用いて Ve

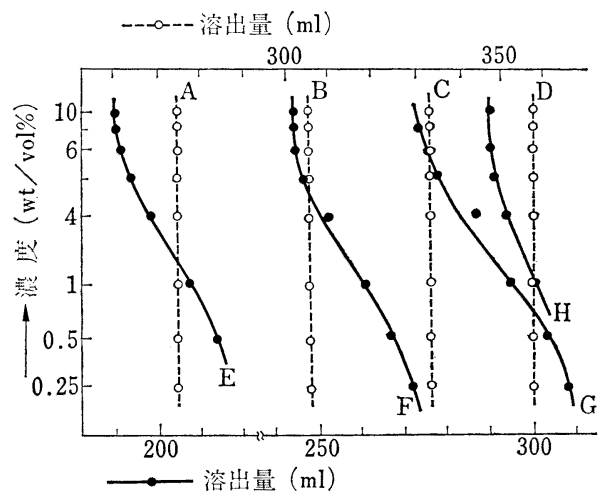

\begin{abstract}
$\mathrm{A}$ : テトラエチレンペソタミン $\mathrm{B}$ : テトラエチレン グリコール C : n-ヘキサデカン $\mathrm{D}: n$-デシルナ ルコール $\mathrm{E}:$ ダイマー酸 $\mathrm{F}:$ オンイン酸 $\mathrm{G}:$ : ジン (アビェチン酸) $\mathrm{H}$ : オクタン酸
\end{abstract}

図-2 各種標準試料の注入濃度と溶出量の関倸 ${ }^{13)}$

表-5 分子量の等しいカルボン酸, エステル及びアルュー ルの溶出量の比較 ${ }^{11}$

\begin{tabular}{c|c|c|c}
\hline 化合 物 & \multicolumn{1}{|c|}{ 子 式 } & 分子量 & \multicolumn{2}{|c|}{$\mid \begin{array}{c}\text { 溶出量 } \\
(\mathrm{ml})\end{array}$} \\
\hline Tridecanoic acid & $\mathrm{CH}_{3}\left(\mathrm{CH}_{2}\right)_{11} \mathrm{COOH}$ & 214 & 266 \\
Pentyl octanoate & $\mathrm{CH}_{3}\left(\mathrm{CH}_{2}\right)_{6} \mathrm{COO}\left(\mathrm{CH}_{2}\right)_{4}-$ & 214 & 319 \\
& $\mathrm{CH}_{3}$ & & \\
Tetradecyl alcohol & $\mathrm{CH}_{3}\left(\mathrm{CH}_{2}\right)_{12} \mathrm{CH}_{2} \mathrm{OH}$ & 214 & 325 \\
\hline
\end{tabular}

カラム・ JAIGEL 4

からカルボン酸の分子量を推定した場合, 注入濃度が 5 \%以上では分子量が約 2 倍の值に得られる。注入濃度が それより低くなるに従いVe は連続的に大きくなり，希 薄溶液ではエステルなどの検量線によってもほぼ妥当な 分子量に対応する位置に溶出されてくる。このことはク ロロホルム中でカルボン酸は, 注入濃度が約 $5 \%$ 以上で は水素結合によって二量体を形成しており，それよりも 低濃度ではカラム内で二量体 ら溶出されてくるものと推測される。平衡は濃度の低下 とともに連続的に単量体側に傾き, 希薄な場合はカラム 内を単量体として挙動するものと考えられる。
図-2 において，ホリエチレンイミンやポリエーテル 及びアルコールについては，この様な Ve の注入濃度依 存性が見られない。

\section{$2 \cdot 3$ 溶媒効果 ${ }^{13}$}

筆者らは分取後の処理等を考慮して, 溶媒には主とし てクロロホルムを使用している。

クロロホルムを溶媒として測定した鎖状化合物の Ve と分子量の関係を 図-3 に破線で示す。ポリエチレンイ ミンやポリエチレングリコールは同じ分子量のパラフィ ンに比べ分子鎖が短いるにもかかわらず，パラフィンよ りも早く溶出されており, Ve が分子サイズと対応して いないように思われる。

溶媒をベンゼンに変えて測定した結果が 図-3の実線 で示されている。この場合にはポリエチレンイミンやポ

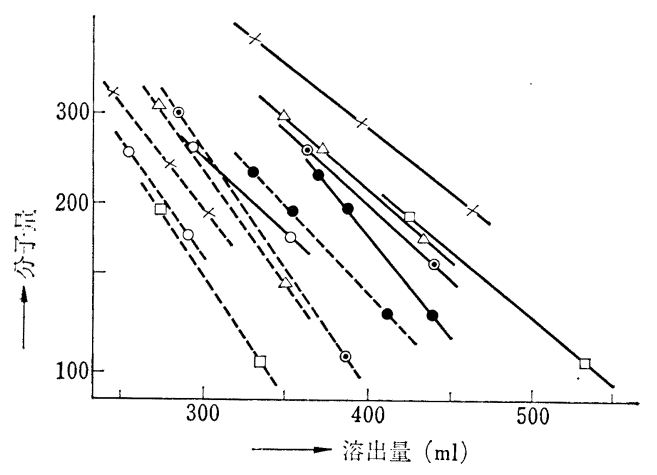

カラム: JAIGEL 4, 溶媒: ベンゼン (実線) 及びク ロロホルム (破線), ○:n-パラフィン，○：アルコ 一ル, $、$ : カルボン酸エステル, $\bigcirc$ : カルボン酸, $\square$ : ポリエチレンイミン, $\times$ : ポリエチレングリコール

図-3 各種鎖状化合物の溶出量に対する溶媒効果 ${ }^{13)}$

リエチレングリコールは炭化水素より後に溶出されてお り，分子サイズとよく対応している。

これらの結果から，ポリエチレンイミンやポリエチレ ングリコールなどはクロロホルム中で溶媒分子と水素結 合等の相互作用して, 見掛けの分子サイズが大きくなっ ているものと思われる。

図-5 から，カルボン酸はベンゼンを溶媒とした場 合 でも他の化合物より早く溶出されていることから，ベン ゼン中においても二量体を形成しているものと考えられ る。

\section{3 分 析 例}

以上の GPC の結果をオリゴマーやポリマーの製品な どの分析に応用し，かつ分取物をIRスペクトルや NMR スペクトルなどによって定性分析を行った例を紹介す る。

\section{$3 \cdot 1$ ゴム加硫促進剂}

試料は暗かっ色の樹脂状物で，加温すると流動性が生 


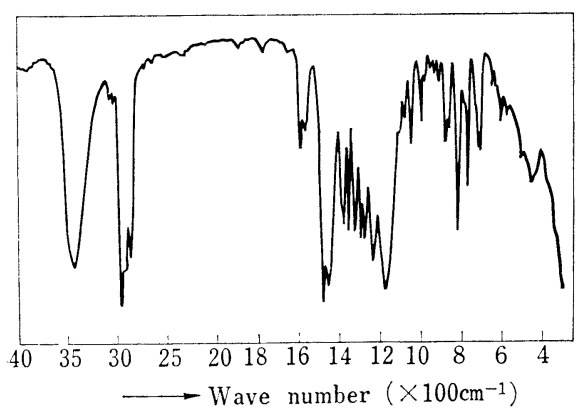

図-4 ت゙ム加硫促進剤の IR スペクトル

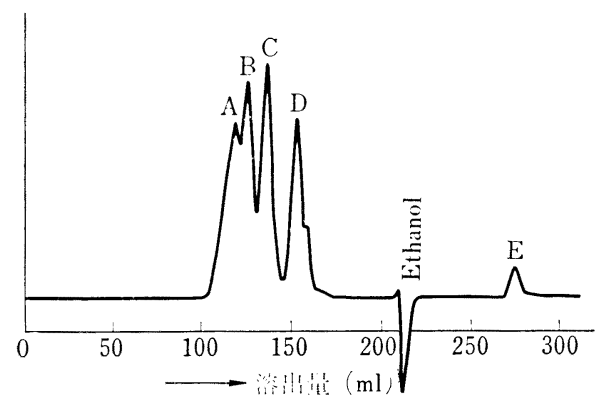

カラム : JAIGEL $1 \mathrm{H}$, 浴媒 : クロロホルム

図-5 ت゙ム加硫促進成の GPC 溶出曲線

じる。IR スペクトル（図-4）から芳香核及びフェノー ル性ヒドロキシル基の存在が推定される。ナトリウム溶 融元素定性分析(以下元素分析という)により硫黄が検出 される。試料をクロロホルムに溶解して測定した GPC 溶出曲線（図-5）には A E の成分が認められ，それら を分取した。スチレンオリゴマーの検量線から推定した $\mathrm{A} \sim \mathrm{D}$ の成分の分子量を 表-6 に示寸。成分 $A \sim D$ の IR スペクトルはいずれももとの試料のスペクトルに類 似していること及び GPC 溶出曲線のパターンから, こ れらの成分は一連のオリゴマーと考えられる。またこれ ら A D D成分には多量の硫黄（約 $22 \%$ ) が認められ ること及びIR スペクトルにおいて $460 \mathrm{~cm}^{-1}$ 付近に $\nu_{\mathrm{s}-\mathrm{s}}$ に基づくと考えられる吸収帯が認められることからポリ スルフィド系化合物と推定される。成分 $\mathrm{E}$ 法赤外不活性 の黄色粉末であり，硫黄と認められる。

成分 $A \sim D$ の NMR スペクトルはいずれも類似して おり，0.65 ppm 付近に分離の良くない三重線 (a), 1.2

表-6 ゴム加硫促進戍の GPC により推定した分子量 及び NMR スペクトルのピーク面積独度比

\begin{tabular}{l|c|c|c|c|c}
\hline \multirow{2}{*}{ 成分 } & 推 & \multicolumn{5}{|c}{ 㳬 } & \multicolumn{4}{|c}{ ピーク 面積強度 比 } \\
\cline { 3 - 6 } & & $\mathrm{a}$ & $\mathrm{b}$ & $\mathrm{c}$ & $\mathrm{e}$ \\
\hline $\mathrm{A}$ & 950 & 3.0 & 5.8 & 2.4 & 2.5 \\
$\mathrm{~B}$ & 800 & 3.0 & 6.0 & 2.6 & 2.6 \\
$\mathrm{C}$ & 615 & 3.0 & 5.9 & 2.4 & 2.7 \\
$\mathrm{D}$ & 400 & 3.0 & 5.9 & 2.3 & 3.0 \\
\hline
\end{tabular}

$\mathrm{ppm}$ 付近に強いピーク (b), $1.6 \mathrm{ppm}$ 付近に b と一部重 なった四重線 (c)，6.2 ppm 付近にブロードなピーク (d), 及び 6.7 7.6 ppm 付近に多重線（e）が認められ

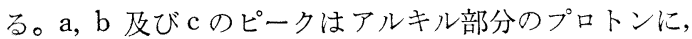
またdのピークは重水添加によって消失することからヒ ドロキシル基のプロトンに，e は芳香核プロトンにそれ ぞれ䚻属できる。a, b c 及び e のピークの積分強度比は 表-6 のとおりである。アルキル部分のピークの強度比 は成分 $\mathrm{A} \sim \mathrm{D}$ ともにあまり変化はみられず，スピンース ピン結合の様子を考慮すると $t$-ペンチル 基及び $t$-ヘキ シル基の混じったものと推定される。成分 $\mathrm{A} \sim \mathrm{D}$ へと分 子量が小さくなるに従い，芳香核プロトンの割合が大き くなる。

これらの結果を総合すると，試料は下記の構造を持っ たオリゴマー（成分 $\mathrm{A}: n \geq 3, \mathrm{~B}: n=2, \mathrm{C}: n=1 \mathrm{D}:$ $n=0)$ 及び少量の硫黄の混合物と認められる。

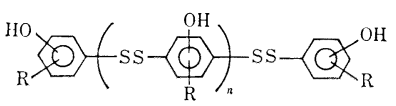

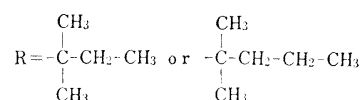

\section{$3 \cdot 2$ 液状接䔔剂}

試料は液状であり加温すると硬化する。元素分析によ り硫黄が検出される。

GPC によって分離するとポリマー成分 $\mathrm{A}$ と, 一連の オリゴマーによると考えられる成分 $\mathrm{B} \sim \mathrm{G}$ ，及びかなり 後の方に成分Hのピークが認められる（図-6)。

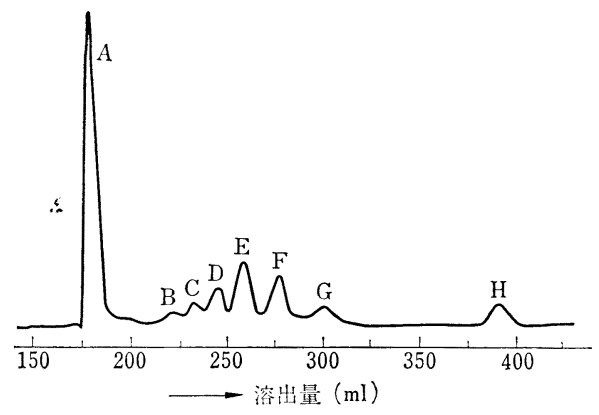

カラム：JAIGEL 4, 溶媒：クロロホルム

図-6 液状接㳙用の GPC 溶出曲線

分取された成分 $\mathrm{A}$ はプラスチック状で, そのIR スペ クトル (図-7A) はビスフェノール $\mathrm{A}$ とフル酸とのポ リエステルのスペクトルに近似している。加水分解する と 2,2-ビス[4-(2-ヒドロキシプロポキシ) フェニル]プ ロパンとフマル酸が得られることから, それらのポリエ ステルと考えられる。

成分 $\mathrm{F}$ は IR スペクトル (図-7F) 及び NMR スペク トル（図-8）からトリエチレングリコールニメタクリル 

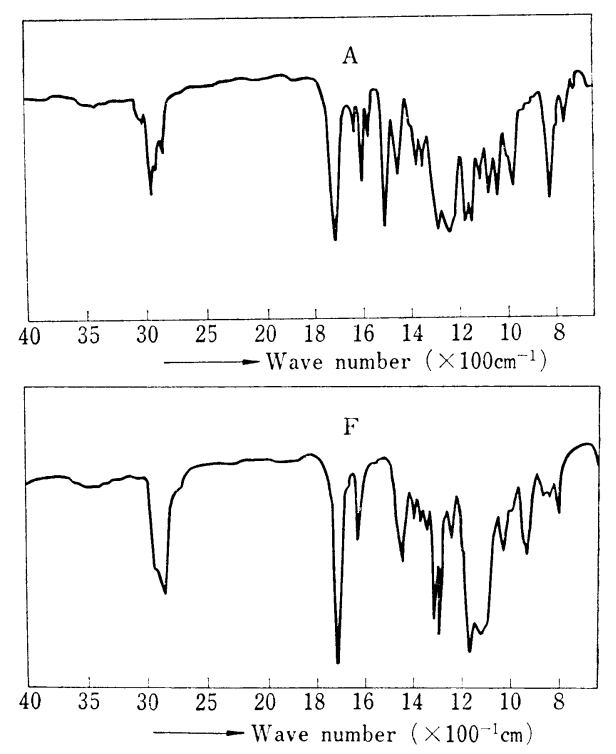

図-7 液状接着剤の GPC 分取成分 $\mathrm{A}$ 及びFの IR スペクトル

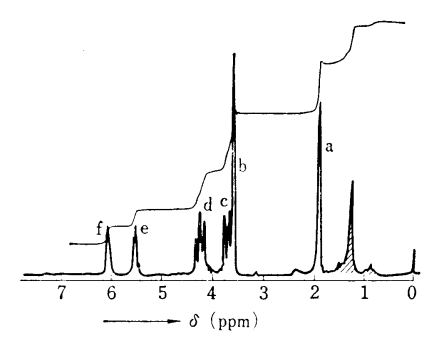

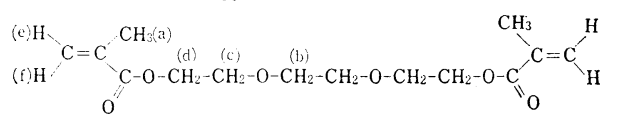

図-8 液状接着剂の GPC 分取成分Fの NMR スペク トル（溶媒：重クロロホルム）

酸ジエステルと考えられる。成分 $\mathrm{B} \sim \mathrm{D}$ 及び $\mathrm{G} の \mathrm{IR}$ ス ペクトルは成分Fのスペクトルに近似しているが 1180 $\mathrm{cm}^{-1}$ 付近のエステルの $\nu_{\mathrm{c}-\mathrm{o}}$ の吸収之 $1120 \mathrm{~cm}^{-1}$ 付近 のエーテルの $\nu_{\mathrm{c}-\mathrm{o}}$ の吸収の強度を比較すると, $\mathrm{B} \sim \mathrm{G} に$ なるに従ってエステルの吸収が相対的に強くなっていく ことから，これらの成分はポリエチレングリコール=メ タクリル酸ジエステルであり, エチレンオキシド基の数 の異なるオリゴマーであると考えられる。

成分Hの IR スペクトルはサッカリンのスペクトルに 一致した。

\section{$3 \cdot 3$ ウレタンフォーム原料}

試料はかっ色の液状物質である。GPC を測定すると 図-9 に示す溶出曲線が得られる。成分 $\mathrm{G}$ の IR スペクト ル (図-10G) にはウレタン結合に基ゔく弱い吸収が存在 するが，他は $4,4^{\prime}$-ジイソシアナトジフェニルメタンの

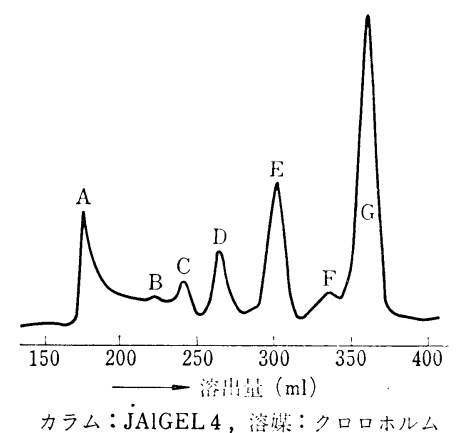

図-9

ウ ウレタンフォーム原料の GPC 溶出曲䋨
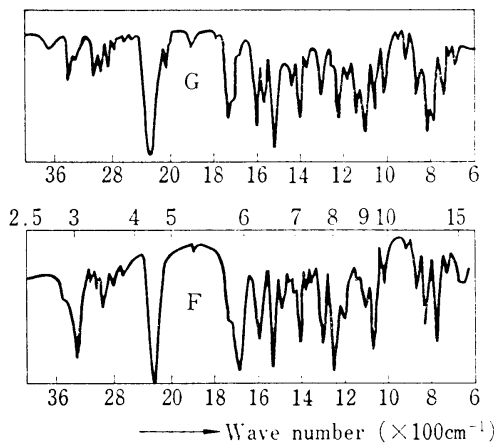

図-10 ウレタンフォーム原料の GPC 分取成分 $\mathrm{G}$ 及び FのIR スペクトル

吸收を主としている。成分 $\mathrm{E} も \mathrm{G}$ と近似した IR スペク トルを示す。これらのNMR スペクトルには芳香核プロ

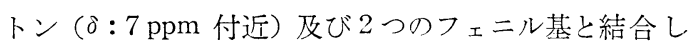
たメチレンプロトン（成分 $\mathrm{G}$ では $3.9 \mathrm{ppm}$ に単一ピー ク, 成分 $\mathrm{E}$ では 3.83 と $3.9 \mathrm{ppm}$ に強度の等しい単一ピ 一クが各 1 本）が認められる。芳香核プロトンとメチレ ンプロトンの比は, 成分 $\mathrm{G}$ では $4: 1$, 成分Eでは 11 :

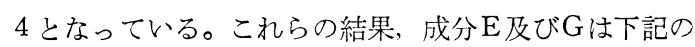
構造で $n=1$ 及び $n=0$ に対応するものと認为られる。

$$
\mathrm{OCN}-\mathrm{O}-\mathrm{CH}_{2}^{* 1}\left(\mathrm{OO}_{\mathrm{NCO}}^{* \mathrm{CH}_{2}}\right)_{n}^{*}-\mathrm{O}-\mathrm{NCO}
$$

成分Eの NMR スペクトルにおいて, メチレンプロト ンのピークが 2 本見られるのは，イソシアナート基がメ 夕位にある場合 $(* 1)$ とオルト位にある場合 $(* 2)$ に対 応しているものと考えられる。

成分 $\mathrm{B} \sim \mathrm{D}$ はVeから上記構造の $n=4 \sim 2$ 亿対応する ものと推定される。

成分 $\mathrm{F}$ の IR スペクトル（図-10F）にはウレタン結 合の吸收ぶやや強く，NMR スペクトルにエトキシル基 の吸收 (1.3 ppm に三重線及び $4.2 \mathrm{ppm}$ に四重線) が 認为られることから $4,4^{\prime}$-ジイソシアナトジフェニルメ タンの一部がエタノールとウレタン結合したものと考え 
られる。

成分 $\mathrm{A} の \mathrm{IR}$ スペクトルも $\mathrm{F}$ と類似しており，より高 分子量のイソシアナート化合物及びそのウレタン化した ものと推定される。

\section{$3 \cdot 4$ ウレタンフォーム添加剤}

試料は無色透明の液体で, 元素分析によりリン及び八 ロゲンが検出される。

GPC の結果，2成分が分取された（図-11)。 成分Aは粘ちゅうな液体であり，IR スペクトル（図一 12A）にはポリエチレングリコール系化合物の吸収に類 似している。NMR スペクトルには $0.09 \mathrm{ppm}$ 付近に

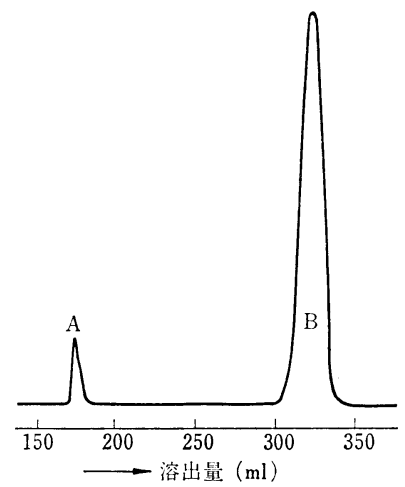

カラム : JAIGEL 4, 溶媒 : クロロホルム

図-11 ウレタンフォーム添加剤の GPC 溶出曲線
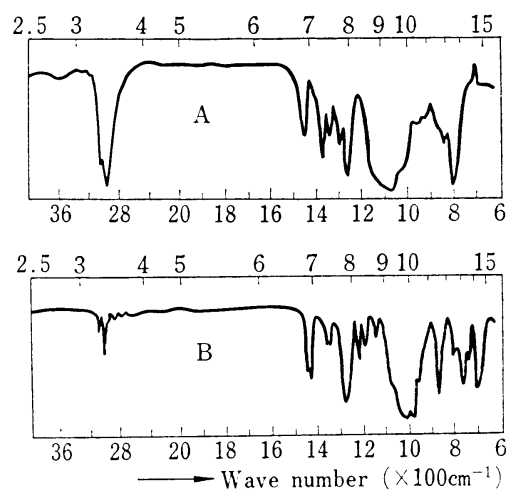

図-12 ウレタンフォーム添加剤の GPC 分取 成分の IR スペクトル

$\mathrm{CH}_{3}-\mathrm{Si}$ の単一線, $1.2 \mathrm{ppm}$ 付近に $\mathrm{CH}_{3}-\mathrm{CH}$-の二重線 及び $3.2 \sim 3.8 \mathrm{ppm}$ 付近に- $\mathrm{CH}_{2}-\mathrm{O}$-及び-CH-O-の多重 線が認めら机る。こ机らの結果, 成分 $\mathrm{A}$ はジメチルシロ キサンーエチレンオキシドープロピレンオキシド重付加物 と考えられる。

成分 $\mathrm{B}$ の IR スペクトル（図-12B）はリン酸エステル の吸収を示している。NMR スペクトルには $4.8 \mathrm{ppm}$ 付 近に二重線がみられ，それとスピンースピン結 合した 2 組の五重線(リンとスピンースピン結 合しているため 2
組に分裂したと考えられる。）が存在し, 前者と後者の ピーク面積比は $4: 1$ である。以上の結果, 成分 Bは難 燃剤として添加されたトリス（1,3-ジクロロ-2-プロピ ル) ホスファートと認められる。

\section{5 接着剂原料}

試料は緑黄色半透明のペースト状である。クロロホル ムによって可溶物と不溶物に分離できる。クロロホルム 不溶物はケイ酸マグネシウム系無機物であった。

クロロホルム可溶物は元素分析によって, 硫黄, 窒素 及びリンが検出される。可溶物は GPC によって 3 成分 が分取された（図-13）。

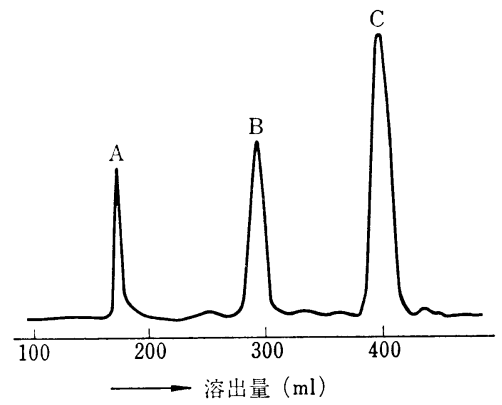

カラム : JAIGEL 4, 溶媒：クロロホルム

図-13 接着剤原料の GPC 溶出曲線

成分 $\mathrm{A}$ は黄色の柔らかい被膜で, IR スペクトル(図-14 A) から芳香族ジイソシアナートとポリエーテル [NMR スペクトルには $1.6 \mathrm{ppm}\left(-\mathrm{C}-\mathrm{CH}_{2}-\mathrm{C}-\right)$ と $3.4 \mathrm{ppm}(-\mathrm{O}-$ $\mathrm{CH}_{2}$-C-）にピーク面積のほぼ等しいブロードなピーク が認められることからポリテトラメチレングリコールと 考えられる。)〕のポリウレタンと認められる。
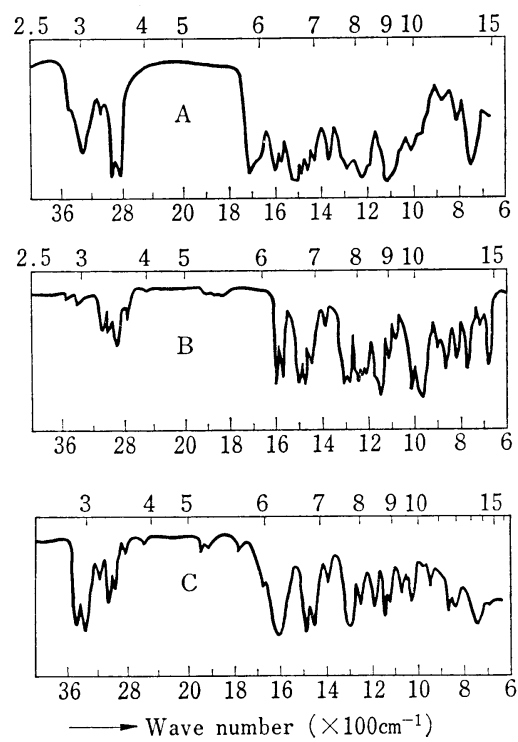

図-14 接着剤原料の GPC 分取成分の IR スペクトル 
成分 $\mathrm{B}$ はリン酸エステルのIR スペクトル (図-14B) を示し, NMR スペクトルには $2.3 \mathrm{ppm}$ 付近 $\left(\mathrm{CH}_{3}-\phi\right)$ と $7.1 \mathrm{ppm}$ 付近 (芳香核) にピークが認奶られ, それ らの面積強度比を教慮してトリトリルホスファートと同 定できる。

成分 C は黄色粘ちゅう液体で, 窒素及び硫黄を含む。 IR スペクトル（図-14C）は ルやそのメチルスルフィド［o-(メチルチオ）アニリン] のスペクトルに類似している。

\section{6 印刷インキ媒質}

試料は黒色ペースト状で, 乾燥すると被膜を形成す る。試料をエチルエーテルに溶解, 分散させ, 活性炭を 添加して黒色顔料を吸着沈殿させて除いた可溶分につい て GPCを行った。得られた溶出曲線を 図-15 に示す。

成分 $\mathrm{A}$ は粘着性のある固体であり, その IR スペクト ル（図-16A）は脂肪酸のグリセリンエステルに近似し ているが，Ve は通常の油脂より小さい。成分 Bも同様 に油脂の IR スペクトルを示し, Ve も乾性油にほぼ一 致する。この結果, 成分 $\mathrm{B}$ は乾性油で, 成分 $\mathrm{A}$ は乾性油 重合物であり, 試料中にはスタンド油等重合乾性油が存 在するものと考えられる。

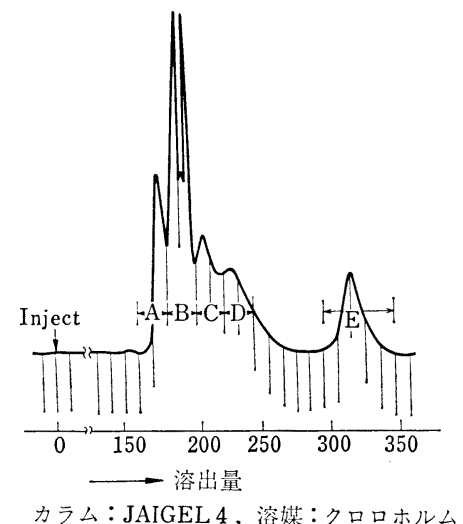

図-15 印刷インキ媒質の GPC 溶出曲線
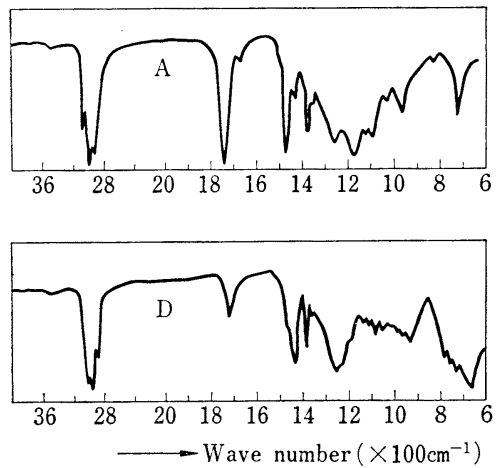

図-16 印刷インキ媒質の GPC 分取成分A及びDの IR スペクトル
成分 $\mathrm{C}$ は樹脂状の固体で, IR スペクトルよりロジン の多価アルコールエステルと認められる。 成分 Dからは八ロゲンが検出され, IR スペクトル （図-16D）は塩素化パラフィンに近似する。

成分Eは IR スペクトル及びVeからアビエチン酸と

認められる。

次㳊透析による分離分析の例を紹介する。

\section{7 高分子疑集剂}

水溶性化合物に対する GPC の充てん剂も開発されて いるが，まだ汎用性のあるものは少なく，特にイオン性 化合物に対するものは見られないようである。

高分子凝集剤についてセルロース透析膜を用いて分離 を試みたところ興味ある結果が得られたので紹介する。

試料は無色透明の粘ちゅうな水溶液であり，アニオン 界面活性剤やテトラフェニルボラート水溶液在滴下する と沈殿を生じる。元素分析の結果, 窒素と八ロゲンを検 出する。

不揮発物の IR スペクトルはブロードであり，咩しい 構造汇関する知見は得られない。不揮発物を重水汇溶解 させて測定した ${ }^{1} \mathrm{H}-\mathrm{NMR}$ スペクトル及び ${ }^{13} \mathrm{C}-\mathrm{NMR}$ ス ペクトルを図-17 に示す。これらのスペクトルだけか ら構造を推定することはかなりむずかしい。

試料の水溶液（不揮発物を約 $1 \%$ 含むように調整） 30 $\mathrm{ml}$ を市販の透析用セルロースチューブに入れ, 約 500 $\mathrm{ml}$ の水を入れたシリンダー中に浸し一昼夜放置した。 使用した透析膜はユニオンカーバイド社製Visking Cel= lulose Tubing 20/32 で, 穴径は $24 \AA$ と称されている。
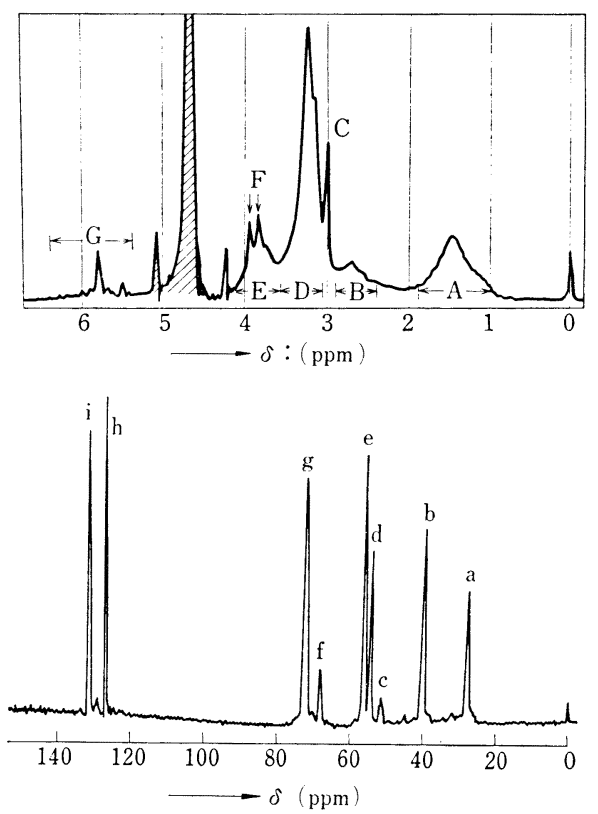

図-17 高分子凝集剂の ${ }^{1} \mathrm{H}-\mathrm{NMR}$ スペタトル及び ${ }^{13} \mathrm{C}-\mathrm{NMR}$ スペクトル（溶媒： $\mathrm{D}_{2} \mathrm{O}$, 外部標 準 TMS) 
透析後膜内外の各水溶液を分取し, 水を蒸発させ, 膜 を通過した成分としなかった成分を得た。膜を通過した 成分の ${ }^{1} \mathrm{H}-\mathrm{NMR}$ スペクトルには 図-17 の， C, F 及び $\mathrm{G}$ のピークがみられ, ${ }^{13} \mathrm{C}-\mathrm{NMR}$ スペクトルには $\mathrm{c}, \mathrm{f}, \mathrm{h}$

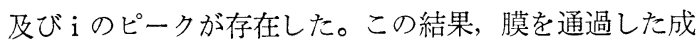
分はジリリルジメチルアンモニウムハライドと認めら れる。

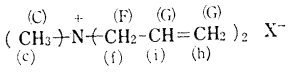

膜を通過しなかった成分の ${ }^{1} \mathrm{H}-\mathrm{NMR}$ スペクトルには $\mathrm{A} ， \mathrm{~B}, \mathrm{D}$ 及びEのピークが， ${ }^{13} \mathrm{C}-\mathrm{NMR}$ スペクトルには

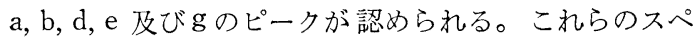
クトル及び膜通過成分を考慮すると膜を通過しなかった 成分はジアリールジメチルアンモニウムシハライドの環 化重合物 ${ }^{14)}$ と考元られる。

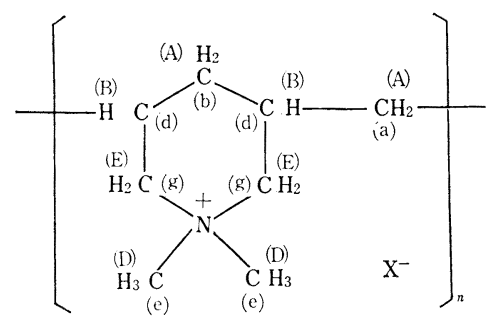

透析膜を通過する割合から，オリゴマーの大まかな平 均分子量が推定できる場合がある。ポリエチレングリコ ールの平均分子量と透析割合をプロットした ところ図-18のような直線関係が得られる 15)。ポリプロピレングリコールについても同 様の関釈が見られるようである。

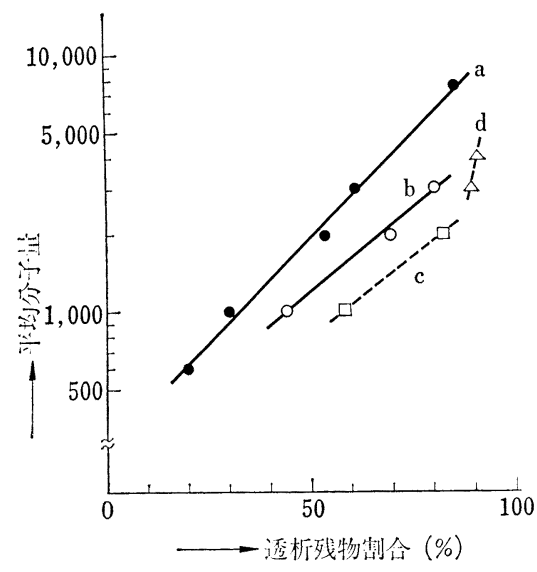

水を溶媒とした PEG（a）及びメタノールー水 (7:3) を溶媒とした PEG (b), ジオール型 PPG(c) 及びトリオール型 PPG (d) 透析時間 : $20 \mathrm{~h}$

図-18 透析膜孛通過しなかった制合と平均 分子量 ${ }^{15)}$

\section{GC-MS によるシリコーンオリゴマー の分析 ${ }^{16), 17)}$}

揮発性化合物に対して, GC-MS は非常に有効な分析 手段である。ここでは, 樹脂やゴムの原料及びはっ水剤, 繊維処理剂等広範囲に利用されているシリコーンオリゴ マーについて，GC-MS による分析例を紹介する。

表-7 及び 表-8 に各種置換基を持ったシリコーンの, IR スペクトル及び NMR スペクトルにおける特性吸収 帯を示した。シリコーンオリゴマーの分析にあたって

表-7 各種シリコーンオリゴマーの赤外スペクトルに お汀る特性吸収帯17)

\begin{tabular}{l|l}
\hline \multicolumn{1}{c|}{ 置換基 } & \multicolumn{1}{|c}{ 特性吸收带 $\left(\mathrm{cm}^{-1}\right)$} \\
\hline $\mathrm{Si}-\mathrm{CH}_{3}$ & $2950,1440,1260$ \\
$\mathrm{Si}-\mathrm{CH}_{3}$ & 800 \\
$\mathrm{CH}_{3}$ & \\
$\mathrm{Si}-\mathrm{CH}_{2} \mathrm{CH}_{2} \mathrm{CH}_{3}$ & $2950,2920,2860,1460$ \\
$\mathrm{Si}-\mathrm{H}$ & 2150 \\
$\mathrm{Si}-\mathrm{O}-\mathrm{Si}$ & 1000,1100 \\
$\mathrm{C}=\mathrm{C}$ & 1595,960 \\
$\mathrm{O}$ & $3050,1600,1490,730,695$ \\
$\mathrm{Si}-\mathrm{OCH}_{2}$ & 2830,1460 \\
$\mathrm{CF}$ & 1210,900 \\
\hline
\end{tabular}

は, まずこれらのスペクトルから試料中の置換基の種類 を推定した後, GC-MS を測定する。

以下の GC-MS のデータは下記の装置及び条件で測定 して得られたものである。

装置 : 島津ガスクロマトグラフ直結質量分析計 LKB9000

カラム $: 3 \mathrm{~mm} \phi \times 2 \mathrm{~m}$, ガラスカラム

表-8 シリコーンオリゴマーの NMR スペクトルにおける特性 吸収 $(\delta: \mathrm{ppm})^{17)}$
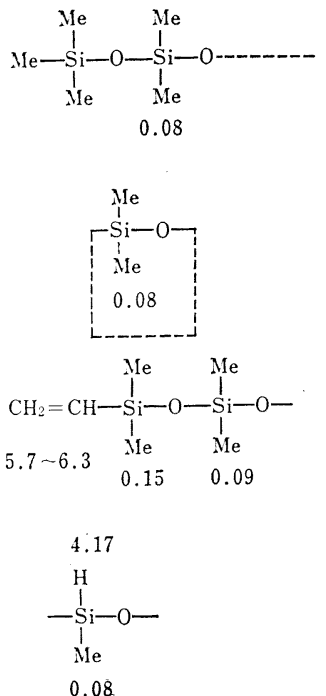<smiles>[Y10][Si](OC)(OC)O[Si]([14CH3])(OC)OC</smiles>

0.17

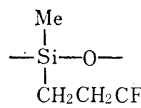
$0.5-0.9 \quad 1.5 \sim 2.5$

0.601 .41 .0 $\mathrm{CH}_{3} \mathrm{CH}_{2} \mathrm{CH}_{3}$<smiles>C=C[Si](C)(C)OC</smiles>

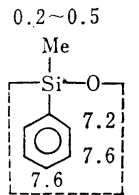

$\mathrm{CH} \mathrm{CH}_{2} \mathrm{CH}_{3}$

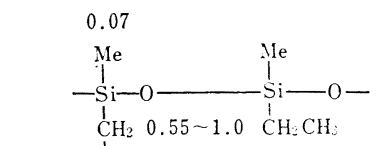

$1.25 \mathrm{CH}_{3} \stackrel{\text { 兵 }}{\mathrm{C}} 2.95 \quad 0.3 \sim 1.0$ 
カラム充てん剤: SE-30 (5\%), Celite 545 (60 80 mesh)

カラム温度 : $50 \sim 250^{\circ} \mathrm{C}$

昇温速度 : $6^{\circ} \mathrm{C} / \mathrm{min}$

検知器: FID

キャリヤーガス : He, $60 \mathrm{ml} / \mathrm{min}$

イオン化電圧 : $70 \mathrm{eV}$

イオン加速電圧 : $1.8 \sim 3.5 \mathrm{kV}$

イオン電流 : $60 \mu \mathrm{A}$

分析例として, 図-19 に少量の環状ジメチルポリシロ キサンを含む，末端ビニルジメチルポリシロキサンの GC を示した。通常はこのよらに一連のオリゴマーのピ ーク群（図-19 の場合E群とC 群）が重なったようなク ロマトグラムが得られる。そこで各ピーク群中の数本の 主なピークについてMS を測定すれば，その一群のオリ ゴマーの定性が可能である。図-19 における $\mathrm{E}_{4}$ と $\mathrm{C}_{4}$ の ピークに対応する MS を図-20 に示した。

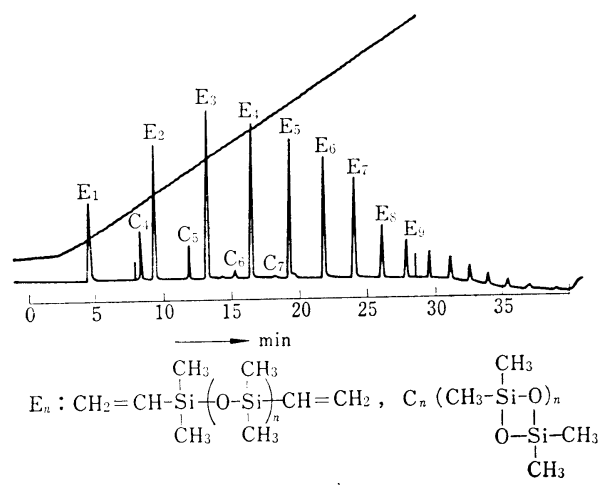

図-19 末端ビニルジメチルポリシロキサン（環状ジメ チルポリシロキサンを含む) の昇温ガスクロマ トグラム ${ }^{17)}$
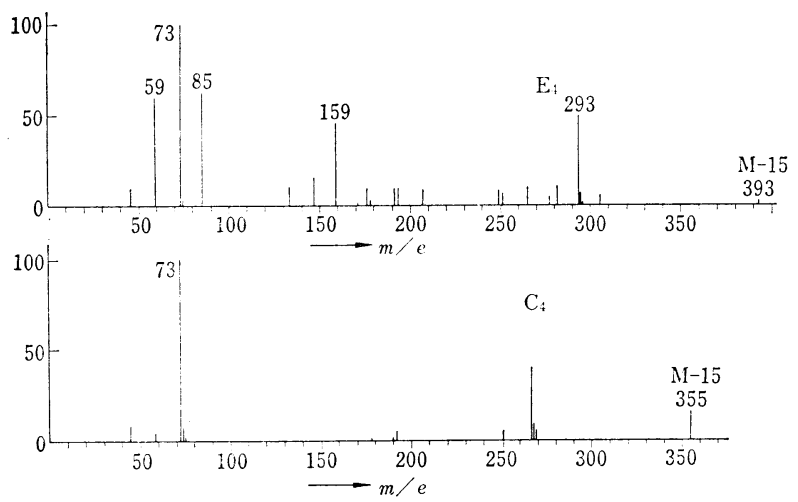

図-20 デカメチルジビニルペンタシロキサン $\left(\mathrm{E}_{4}\right)$ 及びデカメ チルシクロペンタシロキサンの質量スペクトル17

シリコーン系化合物のMSにおいては親イオンのピー クは非常に弱い。Dibeler ら ${ }^{19}$ によると, 親イオンピー クの相対強度はへキサメチルジシロキサンで $0.03 \%$ ，
オクタメチルトリシロキサンで $0.02 \%$ といわれている。 そのため通常の測定では親イオンが観測されずに，メチ ル基が 1 個離脱した M-15 が最大質量数ピークとして認 められる場合が多い。

図-20の $\mathrm{E}_{4}$ のスペクトルでは最大質量ピークとして $m / e 393$ に $\mathrm{M}-15$ のピークの外, $m / e 293$ に $\mathrm{Si}_{4} \mathrm{O}_{3}$ * $\left(\mathrm{CH}_{3}\right)_{7} \cdot \mathrm{CH}=\mathrm{CH}_{2} \cdot \mathrm{H}, m / e \quad 159$ に $\mathrm{Si}_{2}\left(\mathrm{CH}_{3}\right)_{4} \cdot \mathrm{CH}=\mathrm{CH}_{2}$, $m / e 85$ に $\mathrm{Si}\left(\mathrm{CH}_{3}\right)_{2} \cdot \mathrm{CH}=\mathrm{CH}_{2}$ 及び $m / e 73$ に $\mathrm{Si}\left(\mathrm{CH}_{3}\right)_{3}$ に基づくと考えられるイオンピークが認められる。一方 $\mathrm{C}_{4}$ のスペクトルには $m / e$ 159に M-15, m/e 267 に $\mathrm{Si}_{4}$ $\mathrm{O}_{3} \cdot\left(\mathrm{CH}_{3}\right)_{7} \cdot \mathrm{H}_{2}$ ? 及び $m / e 73$ に $\mathrm{Si}\left(\mathrm{CH}_{3}\right)_{3}$ と推定され るピークが観測されている。

文献 17) には上記の外にジメチルポリシロキサン, ヒ ドロゲンメチルポリシロキサン，メトキシメチルポリシ ロキサンの IR スペクトル， NMR スペクトル及び GCMS 並びにジプロピルポリシロキサン，3,3,3-トリフル

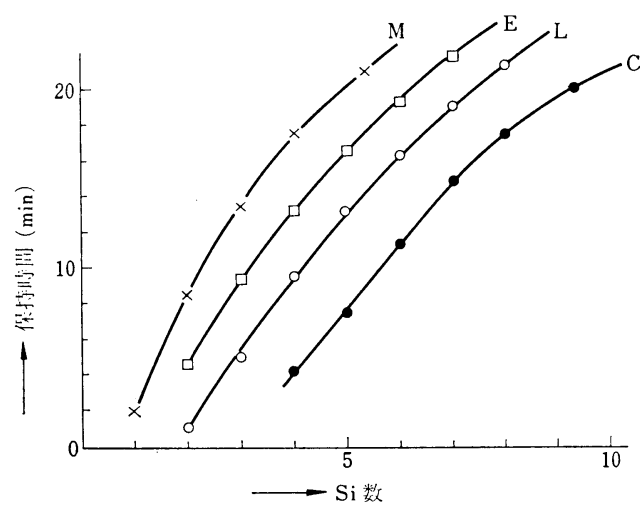

カラム: SE-30(5\%), Celite 545(60 80mesh), $3 \mathrm{~mm} \phi \times 2 \mathrm{~m}$ ガラスカラム, カラム滥度: $50 \sim 250^{\circ} \mathrm{C}$, 昇温速度: $6^{\circ} \mathrm{C} / \mathrm{min}$, キャリヤーガス: $\mathrm{He} 60 \mathrm{ml} / \mathrm{min}$, $\mathrm{L}$ ：鎖状ジメチルポリシロキサン, C : 環状ジメチルポリ シロキサン, $\mathrm{E}$ ：末端ビニルジメチルポリシロキサン, $\mathrm{M}$ :メトキシメチルポリシロキサン

図-21 各種シリコーンオリゴマーの昇温ガスクロマ トグラフィーに括ける保持時間と $\mathrm{Si}$ 数 ${ }^{17)}$

オロプロピルメチルポリシロキサン，フェニルメチ ルシクロポリシロキサン等の IR スペクトル及び NMR スペクトルが示されている。

昇温 GC の場合, 同系列のシリコーンの $\mathrm{Si}$ 数と 保持時間の閒には図-21 に示すような，なめらかな 曲線関係が見られ，保持時閒から重合度が推定でき る。

\section{5 終わりに}

オリゴマーやポリマーの製品には内容末知の場合 が多く，それらの分析には GPC による分取が非常 に役立つ。GPC は充てんゲルによる吸着が極めて少な $く$, 一定時閒内に全成分が溶出され, 実験計画が立てや すい等多くの長所を持っている。 
3 において, GPC による分離 分析例をいくらか揭げ たが, ホットメルト接着剤, 二液性接着剤, チューイン ガムベース, 潤滑油添加剂やゴム老防剂等の同様な分析 例を文献 11）及び 12）に紹介したので，合わせて参照 いただきたい。

水溶性化合物に対する, 透析による分離分析の例を紹 介したが，透析は外部からエネルギーを加える必要がな く, 放置しておけるなどの利点がある。最近, 膜による 分離が注目され, 限外汇過, 逆浸透等分離技術の発展も めざましい。膜の開発も行われているようであり, 今後 の応用が期待される。

以上, 我々の仕事を中心にまとめてみたが, 多少なり ともお役に立てばしあわせである。

\section{（昭和53年10月 25 日受理）}

\section{文献}

1）武内次男, 森 定雄, “ゲルクロマトグラフィー”(基璴編, 応用編), 講談社 (1972)

2) 中村 茂, 分析機器, 11, 105 (1973)

3) 中村 茂, 化学の領域增刊, 109号, p. 71, 南江堂 (1976)

4) 坂田祥光, 三角荘一, 化学の領域増刊, 109 号 p. 79 , 南 江堂 (1976)
5) J.C. Moore, J. Polym. Sci., Part A, 2, 835 (1964)

6) J.C. Moore, J.G. Hendrickson, J. Polym. Sci., Part C, 8, 233 (1965)

7) J.G. Hendrickson, J.C. Moore, J. Polym. Sci., Part $A-1$, 4, 167 (1966)

8) W.B. Smith, A. Kollmansberger, J. Phys. Chem., 69, 4157 (1965)

9) W.W. Schulz, J. Chromatog., 55, 73 (1971)

10) M. Popl, J. Coupek, S. Pokorny, J. Chromatog., 104, 135 (1975)

11）藤田桂一, 早野弘道, 武藤五生, 関税中央分析所報, 16, 9 (1976)

12）関川義明, 藤田桂一, 関税中央分析所報, 17, 41 (1977)

13）藤田桂一, 桑田信一郎, 未発表

14）大森英三，“高分子凝集剤”，p. 40, 高分子刊行会 (1973)

15）桑田信一郎, 小池俊治, 森野博之, 関税中央分析所報, 19, 125 (1978)

16）藤田桂一, 嶋田 勝, 関税中央分析所報, 9, 33 (1969)

17）藤田桂一, 桑田信一郎, 関税 中央 分析所報, 17, 101 (1977)

18）藤田桂一, 化学の領域増刊, 109 号, p. 177, 南江堂 (1976)

19) V.H. Dibeler, F.L. Mohler, R.M. Reese, J. Chem. Phys., 21, 180 (1953)

\section{新版 潤滑の物 理 化学}

\section{トライボロジー叢畫 1}

東京工大名誉教授 桜 井 俊 男著

A 5 判 283 ページ

定価 3,800 円

幸書房発行

自動車のエンジンで生ずる機械エネルギーの内 $30 \%$ 近くがシリンダーライナー/ピストン, 動弁系, ア クスルやミッションなどの摩擦に費されていることを考えると，省エネルギーに占める潤滑の役割がいかに 大きいか理解されよう。かくて省資源，省エネルギーの声が高まるにつれて潤滑問題の重要性が認識されつ つある。本書の刊行は真に時宜を得たものだと思う。

さて, 潤滑の問題を勉強しようと思って図書を探してみると, 機械屋の書いた本はあっても化学屋の書い たものがほとんどないことに気つくく。その点本書の著者は化学屋であり，永年潤滑，潤滑油を専門として研 究してこられた方で, 斯界の第一人者である。

本書は昭和50年に出版された同名著書の改訂版であるが，最近の知見も種々とりいれられており，摩擦， 摩耗, 界面現象, 潤滑油, グリース添加剂等必要な内容は余す処なく盛りこまれている。

潤滑，潤滑油の基礎についてこのような著書のあらわれたことは誠に喜ばしい。新たにこの途に入られる 方の入門書として，またこの方面の仕事にたづさわる方の座右の書として非常に役立つことであろう。

山路 巍 (東亚燃料工業 (株)) 